KONSELING: Jurnal Ilmiah Bimbingan dan Konseling

Vol.1, No.1, Oktober 2019, pp. 35-40

e-ISSN: 2686-2875

https://journal.ilininstitute.com/konseling

DOI: $10.31960 /$ konseling.v1i1.315

Received on 10/09/2019; Revised on 23/09/2019; Accepted on 13/10/2019; Published on:27/10/2019

\title{
Implementasi Assertif Training untuk Meningkatkan Kepercayaan Diri Siswa
}

\author{
Iin Fadli*), Muhammad Ilham Bakhtiar, Salmiati \\ ${ }^{123}$ Bimbingan dan Konseling, STKIP Andi Matappa Pangkep \\ ${ }^{*}$ Correspondence:email.iinfadli@gmail.com
}

\begin{abstract}
Abstrak: Penelitian bertujuan untuk mengetahui pengaruh penerapan teknik Assertif Training untuk meningkatkan kepercayaan diri siswa MTs. DDI Bowong Cindea dan pengaruh penerapan teknik Assertif Training dalam meningkatkan kepercayaan diri siswa. Metode penelitian adalah penelitian eksprimen dengan desain one group pretest post test. Teknik pengumpulan data menggunakan angket dengan sampel sebanyak 35 orang. Hasil Penelitian menunjukkan (1) ada pengaruh tingkat percaya diri siswa sebelum dan setelah perlakuan yaitu menjadi baik (2). Terjadi peningkatan percaya diri setelah diberikan teknik Assertif Training, siswa bernai memilih atas apa yang telah dipilih seperti lanjut studi.
\end{abstract}

\section{Kata Kunci: Teknik Assertif Training, dan Percaya Diri}

\begin{abstract}
The research aims to determine the effect of the application of Assertive Training techniques to improve the confidence of MTs students. DDI Bowong Cindea and the influence of applying Assertive Training techniques in increasing student confidence. The research method is an experimental research design with one group pretest post test. Data collection techniques using a questionnaire with a sample of 35 people. The results showed (1) there was an influence of the level of student confidence before and after treatment that is to be good (2). An increase in confidence after being given Assertive Training techniques, students are entitled to choose what has been chosen as continued studies.
\end{abstract}

Keywords: Assertive Training Techniques, and Confidence

\section{Pendahuluan}

Masa remaja adalah masa transisi antara masa anak menuju masa dewasa. Masa remaja ditandai dengan kematangan seksual yang pada umumnya terjadi antara usia 13 tahun sampai 20 tahun. Siswa yang memasuki usia remaja mengalami perkembangan secara optimal dalam berbagai aspek, antara lain perkembangan fisik, psikologis dan sosial.

Lingkungan, pengalaman, dan pola asuh orang tua mempunyai pengaruh yang signifikan terhadap terbentuknya percaya diri. Pengalaman interaksi siswa dengan orang-orang sekitar, terutama keluarga, perlahan-lahan membentuk kepercayaan diri mereka. Oleh karena itu, siswa yang tumbuh dalam pola asuh yang keliru dan lingkungan yang tidak mendukung, percaya dirinya cenderung tidak dapat berkembang dengan baik. Perkembangan siswa yang diiringi dengan pujian dan penghargaan akan membuat percaya diri mereka berkembang dengan baik. Sebaliknya, perkembangan siswa yang diiringi dengan celaan dan cemoohan akan membuat mereka mengembangkan kepercayaan diri yang kurang baik. 
Siswa yang memiliki percaya diri rendah banyak mengalami kegagalan dan masalah, terutama dalam meraih prestasi yang baik. Menurut Rensi dan Lucia Rini Sugiarti (2010: 148) "kepercayaan diri memiliki pengaruh yang positif terhadap prestasi belajar". Penelitian tersebut dilakukan pada 179 siswa kelas VII sekolah swasta di Semarang, menunjukkan hasil bahwa percaya diri yang dimiliki siswa akan mempengaruhi prestasi belajar yang dicapai. Tingginya kepercayaan diri yang berkembang dalam diri siswa akan mendukung tercapainya prestasi belajar yang baik. Sebaliknya, percaya diri yang rendah akan membuat siswa memiliki prestasi yang rendah. Hal tersebut dikarenakan ketika siswa bersikap pesimis terhadap kemampuan yang dimilikinya dan berpikir bahwa diri akan gagal, sebenarnya mereka telah mempersiapkan kegagalan untuk dirinya.

Berdasarkan hasil wawancara dengan Kepala MTs. DDI Bowong Cindea yakni Bapak Haerul Anwar, S.Pd yang berada dilokasi penelitian MTs. DDI Bowong Cindea, mengemukakan bahwa beberapa siswa dan guru, masih banyak siswa yang menunjukkan indikasi kepercayaan diri yang rendah utamanya dalam pemilihan studi lanjut, percaya diri takut, malu, mencontek dan cemas. Kecemasan dalam menghadapi sesuatu yang berpengaruh terhadap emosi yang dimiliki siswa dan tidak bersemangat pada saat mengikuti pelajaran di kelas, selain itu dapat dilihat dari perilaku siswa yang nampak pada kesehariannya dalam mengikuti kegiatan belajar di kelas seperti jika disuruh guru kedepan kelas selalu merasa takut, selalu cemas terhadap sesuatu hal yang belum terjadi dan selalu bergantung dengan orang lain.

Salah satu permasalahan yang dhadapi siswa belakangan ini adalah terjadinya kecemasan yang dialami oleh seorang siswa dalam memilih jurusan pendidikan yang akan diambilnya ke depan, khusus kepada kelas IX di tingkat MTs, mereka dihadapkan pada jurusan yang tepat bagi dirinya untuk menunjang masa depannya dimasa yang akan datang. Hal ini membutuhkan perhatian dari guru bimbingan dan konseling yaitu bagaimana membina dan membimbing siswa agar kelak dapat bersekolah dijurusan yang sesuati dengan minat belajarnya.

Menurut Kurnia Rizky (2018) Latihan asertif merupakan latihan keterampilan-sosial yang diberikan pada individu yang diganggu kecemasan, tidak mampu mempertahankan hak-haknya, terlalu lemah, membiarkan orang lain merongrong dirinya, tidak mampu mengekspresikan amarahnya dengan benar dan cepat tersinggung

Untuk mengatasi masalah tersebut dibutuhkan kepercayaan tinggi oleh siswa untuk menetapkan sekolah yang akan dipilihnya sehingga tidak ada lagi kesalahan dalam memilih jurusan, dimana minat serta keahliannya tidak sesuai dengan jurusan yang dipilihnya. Melihat hal tersebut upaya yang dapat dilakukan adalah dengan memberikan Assertif Training. Assertif Training merupakan penerapan tingkah laku untuk membantu individu atau kelompok dalam mengembangkan hubungan langsung dalam situasi-situasi interpersonal (Gerald Corey, 2016: 62).

Menurut Herlina (2017) dalam penelitiannya yang berjudul Penerapan teknik assertive training dalam mereduksi konformitas negatif terhadap kelompok sebaya di SMP Negeri 1 Sungguminasa menyimpulkan hasil penelitian bahwa (1) Pelaksanaan teknik assertive training untuk mereduksi konformitas negatif terhadap kelompok sebaya dilaksanakan sesuai dengan prosedur yang sudah dirancang melalui 5 kali pertemuan, (2) Konformitas negatif terhadap kelompok sebaya sebelum penerapan teknik assertive training, berada pada kategori tinggi. Namun setelah penerapan teknik assertive training, berada pada kategori rendah, (3) Penerapan teknik assertive training dalam mereduksi konformitas negative terhadap kelompok sebaya di SMP Negeri 1 Sungguminasa. Artinya siswa yang diberikan penerapan teknik assertive training menunjukkan penurunan tingkat konformitas negatif terhadap kelompok sebaya.

Assertif Training ini diberikan pada individu yang mengalami kecemasan, tidak mampu mempertahankan hak-haknya, terlalu lemah, membiarkan orang lain melecehkan dirinya, tidak mampu mengekspresikan amarahnya dengan benar dan cepat tersinggung sehingga dengan latihan asertif ini diharapkan dapat meningkatkan ketegasan, studi, percaya diri, tidak malu, tidak ikutikutan dan beran menyatakan pendapat. (Singgih Gunarsa, 2015: 26)

Berdasarkan uraian diatas, maka peneliti beranggapan peneliti merasa tertarik untuk mengadakan penelitian dengan judul " Penerapan teknik Assertif Training dalam meningkatkan percaya diri siwa siswa kelas IX MTs. DDI Bowong Cindea Kecamatan Bungoro Kabupaten Pangkep" 


\section{Metode}

Penelitian ini merupakan penelitian eksperimen dalam bentuk pra eksperimen, dimana sampel diberi perlakuan langsung. Lokasi penelitian pada kelas VIII MTs. DDI Bowong Cindea pada semester Genap tahun pelajaran 2018/2019.

Berdasarkan objek yang diteliti dan data yang akan diamati maka penelitian ini termasuk penelitian eksperimen. Variabel dalam penelitian ini dibagi menjadi dua yaitu variabel percaya diri siswa sebelum dan sesudah pemberian teknik Assertif Training sebagai variabel dependen (Y) dan pelaksanaan teknik Assertif Training sebagai variabel indepeneden (X)

Agar diperoleh gambaran keseragaman pembahasan variabel dalam penelitian ini maka secara operasionalnya batasan kedua variabel tersebut adalah sebagai berikut: 1. Assertif Training merupakan suatu kemampuan untuk mengkomunikasikan apa yang diinginkan, dirasakan dan dipikirkan pada orang lain namun tetap menjaga dan menghargai hak-hak serta perasaan orang lain dengan langkah-langkah pelaksanaan meliputi Rasional strategi, Identifikasi keadaan yang menimbulkan persoalan, Membedakan perilaku asertif dan tidak asertif, Bermain peran, Melaksanakan latihan dan praktik, Mengulang latihan, Tugas rumah dan tindak lanjut dan Terminasi. 2. Percaya diri dalam memilih jurusan adalah kesadasaran atau keyakinan seorang siswa atas kesesuaian minat dan kemampuannya memutuskan dan memilih jurusan sesuai dengan minat dan kemampuan belajarnya dimasa yang akan datang. Adapun orang yang percaya diri memiliki ciri -ciri berpikir positif, selalu opitimis, melaksanakan tugas dengan ikhlas, bersemangat dalam bekerja, inovatif, selalu termotivasi dengan hal-hal baru serta berjiwa petarung.

Untuk kepentingan maka dilakukan teknik pengumpulan data sebagai berikut : 1 . Angket adalah pengumpulan data dengan cara mengajukan pertanyaan tertulis untuk dijawab secara tertulis pula oleh responden dengan tujuan untuk memperoleh data dari subyek penelitian. Adapun angket yang digunakan dalam penelitian terkait dengan percaya diri siswa. Data dalam penelitian ini diperoleh melalui angket atau kuesioner yang diberikan kepada kelas yang diberikan layanan bimbingan kelompok. kuesioner tersebut dibuat dan didesain oleh peneliti dengan bantuan pembimbing yang diberikan dalam bentuk 5 item pilihan yaitu: sangat sesuai, sesuai, kurang sesuai, tidak sesuai dan sangat tidak sesuai. 2 . Observasi yaitu aktivitas terhadap suatu proses atau objek dengan maksud merasakan dan kemudian memahami pengetahuan dari sebuah fenomena berdasarkan pengetahuan dan gagasan yang sudah diketahui sebelumnya, untuk mendapatkan informasi-informasi yang dibutuhkan untuk melanjutkan suatu penelitian. Dalam penelitian ini kegiatan observasi dilakukan pada saat pemberian perlakuan serta kegiatan pembelajaran siswa.

Teknik analisis data dalam penelitian ini menggunakan dua jenis analisis yaitu analisis deskriptif dan analisis inferensial. 1. Uji Validitas Data. Uji validitas adalah suatu bentuk analisis yang bertujuan untuk mengetahui apakah instrument yang digunakan dianggap layak atau tidak layak dalam penelitian ini. Adapun uji validitas data dianalisis dengan rumus korelasi product moment, dengan kriteria jika $r_{\text {hitung }}>r_{\text {tabel }}$ makadinyatakan valid dengan taraf signifikansi untuk $\alpha=0.05$. Berdasarkan hasil uji coba instrumen di atas dilaksanakan dengan jumlah responden yang berjumlah 35 orang yang sama besar dengan jumlah sampel, setelah dianalisis dengan taraf signifikan $\alpha=0,05$ dan ternyata diperoleh hasil analisis validitas menunjukkan 46 item angket dinyatakan valid secara keseluruhan. 2. Reliabilitas (Tetap).

Uji reliabilitas data digunakan untuk mengetahui tentang ketetapan data dari hasil penelitian melalui uji coba instrument sebelum diberikan kepada sampel. Adapun rumus reliabilitas data yang digunakan adalah rumus Korelasi Product Moment dengan bantuan program SPSS for Windows versi 22. Berdasarkan hasil perhitungan dengan bantuan program SPSS for Windows versi 22. 3. Uji realibilitas dengan menggunakan program SPSS diperoleh nilai korelasi $r_{\text {hitung }}=0.348$, jika dibandingkan dengan $r_{\text {kritik }}$ pada tabel harga kritik dari $r$ Product-Moment dengan $n=35$ diperoleh $r_{\text {kritik }}=0,254$, ternyata nilai $r_{\text {hitung }}$ lebih besar dari $r_{\text {kritik }}$ atau $0,573>0.312$, oleh karena itu dapat disimpulkan bahwa instrument tersebut dinyatakan reliabel. 4. Uji Hipotesis, dimaksudkan untuk melakukan pengajuan hipotesis yang telah dirumuskan sebelumnya apakah diterima atau ditolak. Untuk melakukan pengujian hipotesis digunakan rumus t-test. 


\section{Hasil Dan Pembahasan}

Analisis statistik deskriptif dimaksudkan untuk memperoleh gambaran mengenai tingkat perilaku bertanggung jawab siswa di MTs. DDI Bowong Cindea Kecamatan Bungoro Kabupaten Pangkep sebelum (Pre test) dan sesudah (Post-test) diberikan layanan konseling dengan teknik Teknik Assertif Training tentang pentingya kepercayaan diri dalam kehidupan sehari-hari .

Kegiatan pretes berlangsung pada hari sabtu tanggal 18 April 2018 dan post-tes pada hari sabtu tanggal 8 Mei 2018. Hasil pretest mengenai penerapan konseling dengan Teknik Assertif Training dalam meningkatkan percaya diri siswa pada MTs. DDI Bowong Cindea Kecamatan Bungoro Kabupaten Pangkep disajikan dalam bentuk tabel distribusi yang klasifikasikan dalam 5 (lima) kategori yaitu tingkat percaya diri sangat baik, baik, sedang, kurang baik, dan sangat kurang baik. Hasilnya seperti berikut pada Tabel. 4.1

\begin{tabular}{cccccc}
\hline \multirow{2}{*}{ Interval } & \multirow{2}{*}{ Kategori } & \multicolumn{2}{c}{ Pre-test } & \multicolumn{2}{c}{ Post-test } \\
\cline { 3 - 6 } & Sangat baik & 0 & $0 \%$ & Frekuensi & Persentase \\
\hline $97-115$ & Baik & 0 & $0 \%$ & 20 & $37,5 \%$ \\
$80-96$ & Sedang & 17 & $43,75 \%$ & 0 & $62,5 \%$ \\
$61-79$ & Kurang baik & 18 & $56,25 \%$ & 0 & 0 \\
$42-60$ & Sangat kurang baik & 0 & $0 \%$ & 0 & 0 \\
$23-41$ & Jumlah & $\mathbf{3 5}$ & $\mathbf{1 0 0}$ & $\mathbf{3 5}$ & $\mathbf{1 0 0}$ \\
\hline
\end{tabular}

Berdasarkan data Tabel 4.1 tampak bahwa dari 35 orang responden penelitian pada saat pretest telah diketahui bahwa ada 18 orang $(56,25 \%)$ yang berada pada kategori tingkat percaya diri siswa yang kurang baik, dan $17(43,75 \%)$ yang berada pada kategori tingkat percaya diri siswa sedang, sedangkan untuk kategori sangat baik, baik dan sangat kurang baik, tidak ada responden yang masuk kategori.

Kemudian setelah dilakukan pre-test, selanjutnya klien diberi perlakuan berupa Penerapan Assertif Training dalam meningkatkan percaya diri siswa, kegiatan ini berlangsung selama 3 hari yakni dari hari senin 21 April 2018 sampai dengan rabu 23 April 2018. Adapun kegiatan ini dengan memberikan kegiatan teknik Assertif Training dalam meningkatkan percaya diri siswa kemudian dilakukan penyimpulan oleh seluruh anggota kelompok serta dilakukan sesi tanya jawab.

Setelah siswa atau responden diberikan layanan teknik Assertif Training maka diketahui bahwa tingkat perilaku sosial positif siswa di MTs. DDI Bowong Cindea Kecamatan Bungoro Kabupaten Pangkep mengalami peningkatan. Hal ini sesuai dengan hasil post-test bahwa dari 35 orang yang diteliti, ternyata ada $20(62,5 \%)$ responden mengalami peningkatan percaya diri siswa baik, dan $15(37,5 \%)$ responden mengalami peningkatan dalam kategori sangat baik. Jadi tidak ada lagi siswa yang memiliki percaya diri siswa dengan kategori sedang, kurang baik, dan sangat kurang baik. Demikian dapat disimpulkan bahwa sebelum pemberian perlakukan berupa teknik Assertif Training dalam meningkatkan percaya diri siswa yang berkategori kurang baik, dimana pada kategori kurang baik ini artinya siswa belum memahami arti percaya diri itu seperti apa sehingga belum tertanam dalam diri siswa, dan setelah pemberian perlakuan berupa teknik Assertif Training dalam meningkatkan percaya diri siswa telah mengalami peningkatan menjadi kategori baik dimana pada kategori baik ini artinya pemberian perlakuan atau pelaksanaan teknik Assertif Training dalam meningkatkan percaya diri siswa pada siswa telah berhasil karena mengalami perubahan dan berperan penting dalam meningkatkan percaya diri siswa serta sudah mulai tertanam sikap berani. Jika ini diterapkan maka akan berdampak positif pada siswa disekolah.

Secara umum penerapan teknik Assertif Training bermaksud memberikan pembahasan kepada siswa yang berkepentingan berbagai hal yang diperlukan untuk menjalani suatu arah dan tujuan yang dikehendaki. Dengan demikian, penerapan teknik Assertif Training merupakan suatu bentuk konseling dalam rangka memberikan pandangan-pandangan serta penguatan-penguatan positif yang diharapkan mampu merubah perilaku siswa yang lebih baik.

Hasil penelitian ini, di dukung oleh Soetarlinah Sukadji (Edi Purwanta, 2005: 35) menyatakan apabila suatu stimulus berupa benda atau kejadian itu dihadirkan (yang terjadi sebagai akibat atau konsekuensi suatu perilaku) secara berulang-ulang, sehingga keseringan munculnya 
perilaku tersebut meningkat atau terpelihara, maka peristiwa itu akan mampu meningkatkan menjadi lebih baik dan terarah.

Dari pendapat tersebut maka setiap perubahan yang muncul dari siswa melalui satu bentuk perlakuan diharapkan akan menimbulkan perubahan positif dimana perubahan tersebut tanpa disadari langsung oleh siswa sebagai subyek perlakuan. Pada umumnya percaya diri siswa merupakan perwujudan dari perubahan perilaku dan kebiasaan siswa dalam mengontrol perilakuperilaku yang tidak sesuai sehingga tidak ada lagi pelanggaran-pelanggaran yang diakibatkan oleh perilaku siswa tersebut secara sengaja.

Perilaku bertanggung jawab siswa di MTs. DDI Bowong Cindea Kecamatan Bungoro Kabupaten Pangkep menjadi subyek penelitian, Hasil penelitian menunjukkan bahwa siswa sampai pada saat mengerjakan angket sebelum perlakuan hasilnya menunjukkan kategori perilaku bertanggung jawab yang rendah. Namun setelah diberikan perlakuan berupa penerapan teknik Assertif Training dalam meningkatkan percaya diri siswa mengalami peningkatan menjadi baik. Hal ini menunjukkan perubahan positif yang signifikan, itu berarti bahwa tingkat percaya siswa mengalami peningkatan pada umumnya dari kategori sedang menjadi kategori baik.

Berdasarkan hasil analisis statistik diperoleh bahwa nilai t-hitung pada umumnya lebih besar dari t-tabel sehingga t-tabel < t-hitung maka konsekuensinya adalah hipotesis kerja (ha) yakni teknik Assertif Training berpengaruh terhadap peningkatan percaya diri siswa di MTs. DDI Bowong Cindea Kecamatan Bungoro Kab. Pangkep dinyatakan diterima. Kemudian dari hasil penelitian melalui uji korelasi product moment diperoleh nilai "r" sebesar $0,07=7 \%$ sehingga nilai tersebut berada pada rentang 0 - 20 dengan kategori sangat rendah. Dengan demikian pada hakekatnya terdapat perubahan kategori perilaku bertanggung jawab siswa karena telah diberikan perlakukan berupa layanan konseling dengan teknik Assertif Training dalam meningkatkan percaya diri siswa.

Hasil ini sejalan dengan hasil penelitian yang dilakukan oleh Herlina, (2017) yang berjudul Penerapan teknik assertive training dalam mereduksi konformitas negatif terhadap kelompok sebaya di SMP diperoleh hasil bahwa (1) Pelaksanaan teknik assertive training untuk mereduksi konformitas negatif terhadap kelompok sebaya dilaksanakan sesuai dengan prosedur yang sudah dirancang melalui 5 kali pertemuan, (2) Konformitas negatif terhadap kelompok sebaya sebelum penerapan teknik assertive training, berada pada kategori tinggi. Namun setelah penerapan teknik assertive training, berada pada kategori rendah, (3) Penerapan teknik assertive training dalam mereduksi konformitas negative terhadap kelompok sebaya di SMP Negeri 1 Sungguminasa. Artinya siswa yang diberikan penerapan teknik assertive training menunjukkan penurunan tingkat konformitas negatif terhadap kelompok sebaya.

Dengan demikian dapat disimpulkan bahwa dalam rangka peningkatan kepercayaan diri siswa perlu dilakukan teknik Assertif Training sebagai suatu cara yang baik dan positif dalam meningkatkan kepercayaan diri siswa di MTs. DDI Bowong Cindea Kecamatan Bungoro Kabupaten Pangkep.

\section{Simpulan Dan Saran}

Hasil penelitian mengenai "teknik Assertif Training dalam meningkatkan percaya diri siswa di MTs. DDI Bowong Cindea Kecamatan Bungoro Kabupaten Pangkep" disimpulkan sebagai berikut : 1 . Tingkat percaya diri siswa MTs. DDI Bowong Cindea Kecamatan Bungoro Kabupaten Pangkep sebelum perlakuan dikategorikan "tidak baik". Dan tingkat percaya diri siswa MTs. DDI Bowong Cindea Kecamatan Bungoro Kabupaten Pangkep setelah perlakuan dikategorikan "baik". 2. Teknik teknik Assertif Training dapat meningkatkan percaya diri siswa di MTs. DDI Bowong Cindea Kecamatan Bungoro Kabupaten Pangkep. Artinya semakin diberikan teknik Assertif Training maka percaya diri siswa akan semakin meningkat

\section{Daftar Rujukan}

Centi, J.Paul. 2003. Mengapa Rendah Diri. Kanisius. Yogyakarta

Corey, Gerald. 2016. Teori dan Praktik Konseling\&Terapi. Bandung: PT Refika Aditama 
KONSELING: Jurnal Ilmiah Bimbingan dan Konseling

Vol.1, No.1, Oktober 2019

Available online: https://journal.ilininstitute.com/konseling

Iin fadli, Muhammad Ilham Bakhtiar, Salmiati

Fauzan, Lutfi. 2007. Assertive Training: Pengembangan Probadi Asertifdan Transaksi Sosial. Depdiknas: UPT BK UM

Ghufron, 2010. Upaya Menurunkan Kecemasan Siswa Menghadapi Ujian Menggunakan Teknik Desensitisasi Sistematis Pada Siswa Kelas VIII Unggulan SMP Negeri 1 Abung Semuli Lampung Utara Tahun Pelajaran 2010-2011. Skripsi: Universitas Lampung

Goldstein, 2017. Latihan Asertif., diakses di www./konselingsmkn2plg.blogspot.com/201 2/08/latihan-asertif.html update 07 Agustus 2017.

Hakim, Thursam. 2005. Mengatasi Rasa Tidak Percaya Diri. Puspa Swara.Jakarta

Haryanto, 2010. Bimbingan dan Konseling Edisi Revisi, PT Raja Grafindo Persada, Jakarata

Kartini Kartono \& Dali Gulo, 2011. Pengantar Psikologi Abnormal. Bandung: Rineka Aditama

Kurnia Rizky. 2018, teknik konselig assertif training. diakses di http://misscounseling.blogspot.co.id. Update 29 Maret 2018

Media, 2018, Penerapan Teknik Assertive Training, diakses di http://Media.Neliati.com di update 24 Juli 2018.

Mustika, 2007. Manajemen Stres, Cemas dan Depresi. Jakarta: Gaya Baru

Nana Sudjana. 2004. Tuntunan Penyusunan Karya Ilmiah.Bandung Sinar baru Algesindo.

Prayitno. 2013. Layanan Bimbingan dan Konseling Kelompok Dasar Dan Profil. Jakarta : Ghalia Indonesia.

Rensi dan Lucia Rini Sugiarti, 2010. Pengantar Psikologi Edisi ke Delapan Jilid 2. Jakarta: Erlangga

Singgih Gunarsa, 2015. Kesehatan Mental dalam Kehidupan. Jakarta: Rineka Cipta

Soelaeman Joesoef, 2000. Kecerdasan Emosional. Diterjemahkan oleh Hermaya. Jakarta: PT. Gramedia Pustaka Utama

Sugiyono,2007. Metode Penelitian Pendidikan (Pendekatan Kuantitatif, Kualitatif, dan R\&D). Bandung: Alfabeta

Thantawy. 2005. Kamus istilah bimbingan dan konseling. diakses di http//ilmu psikologi word press.com. Update 29 Maret 2018

Tulus Winarsunu, 2006. Konseling Individual Teori dan Praktek. Bandung: Alfabeta.

Yusuf Luxori, 2005. Psikologi Suatu Pengantar Edisi Ke Dua Jilid 2. Jakarta:Erlangg 